\title{
Microeconomic Competitiveness And Post- Conflict Reconstruction: Firm-Level Evidence From Zimbabwe
}

\author{
Marianne Matthee, North-West University, Potchefstroom Campus, South Africa \\ Waldo Krugell, North-West University, Potchefstroom Campus, South Africa \\ Macleans Mzumara, North-West University, Potchefstroom Campus, South Africa
}

\begin{abstract}
This paper examines the micro-level factors that constrain Zimbabwean firms in the country's post-conflict environment. An analysis was conducted into what Zimbabwean firms see as their most debilitating obstacle to achieving higher levels of competitiveness. Among the findings was that so-called non-politically constrained firms face many challenges in their day-to-day operations, which often points to internal strategic and operational shortcomings. Politically constrained firms, on the other hand, have progressed to a stage where their internal systems are in good shape, but their future vision and goals are potentially threatened by the unstable political situation in the country. This creates uncertainty, which can impact negatively on ongoing investment and expansion.
\end{abstract}

Keywords: Zimbabwe; Post-Conflict; Firm-Level; Competitiveness

\section{INTRODUCTION}

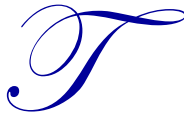

he competitiveness of regions, countries and firms is a key driver of economic growth and development, and is of growing concern to researchers and policymakers alike. A considerable amount of work done in the field of competitiveness has focused on politics, institutions, society and the macro-economy, but recently, Porter reiterated that while these are necessary, they are not sufficient conditions to create wealth (Porter, 2003). He argued that economic growth is the result of firms being productive. These firms' ability to compete depends on two factors: the sophistication of their corporate strategy and operations, and the quality of the microeconomic business environment (Porter, 2003). Therefore, microeconomic competitiveness needs to be put under the spotlight and nowhere is this topic more pertinent than in the case of post-conflict or postcrisis economies.

Post-conflict or post-crisis reconstruction and development is a complex process. Along with the need to restore political order, social and economic renewal is called for. When it comes to rebuilding the economy, postconflict reconstruction involves establishing an environment that is conducive to economic growth. This includes rehabilitating physical economic infrastructure such as roads and bridges, restoring the water supply, and bringing the sanitation, energy and power services back into operation (Mlambo, Kamara and Nyenda, 2009). It also entails less tangible steps such as demonstrating a commitment to greater policy certainty and more inclusive institutions. Brück, Naudé and Verwimp (2011) emphasised the importance of formulating public policies so as to recreate an environment in which entrepreneurship can thrive. In particular, the microeconomic environment should be such that it enables firms to operate at full capacity, thereby generating employment opportunities and contributing to economic growth.

Research into the microeconomic aspects of post-conflict reconstruction is limited, as indicated by Collier and Duponchel (2013). These authors conducted the first study in this regard, which involved a microeconomic analysis of the post-conflict reconstruction of Sierra Leone. Among their findings was that firms tend to be smaller 
in those areas where the conflict (or war) was more intense. They also found that production capacity is often constrained by the degeneration of skills, which they termed "forgetting by not doing" (Collier and Duponchel, 2013:67). This paper aims to add to the literature in the field by focusing on the case of Zimbabwe.

Zimbabwe is classified as a post-conflict country (Ali, 2009; Makochekanwa and Kwaramba, 2009, African Development Bank, 2010, World Bank, 2011a). In September 2008, a Global Political Agreement (GPA) was signed by the Zimbabwe African National Union Patriotic Front (ZANU-PF) and two strands of the Movement for Democratic Change (MDC), heralding the start of a much-anticipated period of recovery for the country. This agreement led to the installation of a Government of National Unity (GNU) on 11 February 2009 (African Development Bank, 2010:2; World Bank, 2011a). According to the African Development Bank (2010:2) and the World Bank (2011a), the formation of the GNU provided the impetus to begin a process of reconstruction through the implementation of a range of economic growth strategies. These included the Short Term Emergency Recovery Programme (STERP) I, the Short Term Emergency Recovery Programme (STERP) II and the Medium Term Plan (MTP), which would cover the period 2010 to 2015. At a national level, these strategies have had some positive effects. For example, the runaway hyperinflation that the country once experienced has been reined in and positive economic growth rates are now being achieved (African Development Bank, 2010:2; World Bank, 2011a).

Despite there being a more stable macroeconomic environment, firm-level output is still far off its precrisis levels. According to the World Bank (2011a), capacity utilisation in Zimbabwe's manufacturing sector stands at between 30 and $40 \%$. The agricultural sector is also operating well below par compared with the pre-crisis days. At this rate, it is estimated that it could take at least a decade for firms to achieve their pre-crisis levels of output. So what are the micro-level factors that are constraining Zimbabwean firms? Are firms trapped in a low growth cycle because they are still relying on old or inadequate capital equipment, or do they lack the necessary skills? Might the state of the country's infrastructure be an influencing factor, or access (or non-access, as the case may be) to finance? Is there uncertainty surrounding the government's policy framework that is discouraging firms from doing business?

An enterprise survey conducted by the World Bank (2011b) showed that for approximately $45 \%$ of firms in Zimbabwe, access to finance is their biggest hurdle. Another $30 \%$ see political instability as their biggest hurdle. A more detailed breakdown of the survey data revealed that the size of the firm is a factor in how business challenges or obstacles are viewed. For example, fewer small- and medium-sized firms view political instability as a constraint. Where small firms do believe that they are held back by the political climate, it is because they are uncertain about market prospects and see corruption as a significant impediment to doing business.

The aim of this paper is to explore the micro-level factors that constrain Zimbabwean firms in the country's post-conflict era. The analysis starts with some reflections on the consequences of conflict, as well as the aims and phases of, and strategies associated with, reconstruction. The spotlight is then placed on Zimbabwe as a post-conflict economy and the different manifestations of its reconstruction effort. Finally, a link is established between reconstruction and microeconomic competitiveness, and the empirical findings from the World Bank Enterprise Survey on firm competitiveness are presented.

\section{UNDERSTANDING CONFLICT AND RECONSTRUCTION}

According to the World Bank (1998), more than 50 countries have gone through periods of conflict since 1980. In 2008, the United Nations Development Programme (UNDP) produced a list of 35 countries that have experienced conflicts and have gone through, or are still in the throes of, post-conflict reconstruction. Many of these were initially referred to as Low Income Countries Under Stress (LICUS). The World Bank has since replaced this definition, first adopted in 2002, with its own term, 'fragile states', which refers to post-conflict countries (Guillaumont and Jeanneney, 2009:4). The Development Aid Committee (DAC) of the Organisation for Economic Cooperation and Development (OECD) defines a 'fragile state' as a country that lacks both political commitment and the necessary capacity to formulate and implement pro-poor policies (Guillaumont and Jeanneney, 2009:3). In the UNDP's (2008a:7) list of 35 post-conflict countries, 17 are in Africa. Similarly, according to the fragile states list compiled by the World Bank (2013), 19 countries are located in Africa. 
The UNDP (2008a:7) assigns post-conflict countries to three categories. At the one extreme are countries where the level of violence was so great that it brought about the collapse of the state. Countries in this category include Liberia, Bosnia and Herzegovina, the Democratic Republic of Congo (DRC), Sierra Leone and Somalia. At the other extreme are countries such as Guatemala, Sri Lanka and the former Yugoslav Republic of Macedonia that have emerged from conflict with their political and economic structures very much intact. Between these two extremes are countries such as Angola, Côte d'Ivoire, El Salvador, Mozambique, Burundi and Sudan where violence had a negative impact on a large proportion of the national territory and the level of physical destruction was significant.

The UNDP (2005) asserts that a conflict, by definition, involves the diversion of resources from production to destruction. The wholesale destruction of legitimate economic activity is, in turn, replaced by shadow economies or illegal activities. A conflict reduces the level of economic activity in two ways. Firstly, there is the physical destruction of infrastructure and the means of production. Secondly, there is dissaving and capital flight (both human and financial) (Reinikka and Collier, 2001).

Given the consequences of conflict, a range of strategies, policies and adjustments need to be introduced for reconstruction to take place (World Bank, 1998:2). Economic recovery is important to overcome the negative fallout from conflicts (UNDP, 2008a: xvii, 3). However, there are potential short-term dangers associated with a reconstruction effort. For example, a country could lapse once again into disarray if reconstruction policies discriminate against certain groups of people (which only leads to renewed tension), if there is weak governance, or if the state fails to deal decisively with corruption. Economic failure tends to render institutions ineffective (Michailof, Kostner and Devictor, 2002), which often deals a fatal blow to the reconstruction effort.

Post-conflict reconstruction has two major objectives: facilitating the transition from war or conflict to sustainable peace, and creating an environment that supports economic and social development. The first objective can be achieved through peace-making and (mainly international) peace-keeping interventions. The second objective calls for the peacetime economy to be re-built within the shortest time possible and for the state-society relationship to be re-established (World Bank, 1998).

Collier, Hoeffler and Söderbom (2008) outlined six stages that can be followed in bringing about reconstruction. The first stage is aimed at reaching an amicable negotiated settlement while keeping further hostilities at bay. The second stage involves the actual act of negotiation and arriving at a settlement. The third stage involves writing a Constitution that guarantees people their democratic rights. The fourth stage involves the drafting and implementation of specific reforms, with the domestic government taking the lead in this regard and the international community offering guidance. The fifth stage involves ensuring the political legitimacy of the settlement and the government through the holding of post-conflict elections. The sixth and last stage involves the international peace-keeping forces exiting the country.

Anderlini and El-bushra (2004) also identified different phases in the reconstruction process that usually overlap to some extent. The first phase involves the provision of emergency humanitarian assistance after the violence has come to an end. This phase focuses on creating stability and providing security, with the UN deploying peace-keeping forces. The second phase is the transition, in which efforts are made to jump start the economy. This phase is characterised by the rebuilding of infrastructure destroyed during the conflict, the establishment of government structures, the revival of an independent judiciary system, and the restoration of basic services, such as health and education, and is rounded off by the emergence of local expertise. The final phase, which sees the recovery process taking root and starting to bear fruit, places a heavy emphasis on implementation to prevent the conflict from recurring. In this phase, too, the peace-keeping forces begin to leave the country and a sense of normality returns to society.

Nhema and Zeleza (2008) proposed a range of post-conflict reconstruction strategies specifically suited to Africa. They include: advocating a stronger and more visible role for African regional groupings; demobilising and resettling the combatants; repatriating refugees and internally displaced people; removing land mines; banning the acquisition of military supplies from other countries/external organisations; organising multi-party elections; ensuring active participation from all branches of civil society; resuscitating local communities by introducing 
proper democratic processes, such as ensuring that elections are fair, establishing accountable institutions, distributing income and resources in a more equitable manner, promoting human rights, and soliciting external donor funding. Of course, no single one of the above measures can solve the multi-dimensional problems confronting African countries that are emerging from conflict. A blended solutions package is always required (Nhema and Zeleza, 2008). Furthermore, The United Nations (2002) advocates the inclusion of women in the postconflict strategy development process in Africa.

\section{THE CASE OF ZIMBABWE}

Zimbabwe, which appears on the World Bank's list (2013) of fragile states, suffered severe internal conflict and an economic crisis of epic proportions during the period 2000 to 2008 . There has been much debate about what gave rise to the turbulence in the country, but violence, intimidation and denial of political participation (The Catholic Commission for Justice and Peace in Zimbabwe, 2001; Parsons, 2007; MMPZ, 2009) were ever present. The international community has blamed the ZANU-PF government's ill-conceived policies, specifically land reform, for the economic meltdown. The government, in turn, has attributed the economic crisis to international sanctions. This paper does not dwell on the causes of the conflict in Zimbabwe, but rather recognises that the country has moved into a post-conflict era and appropriate reforms are required if positive economic growth is to become the new norm.

Zimbabwe acquired Low Income Countries Under Stress (LICUS) status in the financial period 2003-2005 (Anderson, 2005; Anderson, Christiansen and Putnam, 2007). One of the hallmarks of the economic crisis that gripped the country was hyperinflation, which reached a crescendo in 2007 and 2008 (IMF, 2010). Despite the government's revenue base having shrunk, the Reserve Bank of Zimbabwe continued to print money to ensure that the government could continue to discharge its obligations. Inevitably, inflation began to spiral out of control. ZIMSTAT stopped publishing inflation figures on a regular basis in the hope that during the lull in reporting the economy would improve and a more positive result could be announced the next time round (Parsons, 2007). This did not happen. The highest inflation rate recorded in 2008 had a mindboggling 10 digits (ZIMSTAT, 2010). Eventually, the Zimbabwean dollar was abandoned in favour of a multi-currency regime (specifically the United States dollar and the South African rand).

According to Parsons (2007), global experience suggests that runaway inflation usually comes packaged with many other policy mistakes, the accumulation of which often has disastrous economic consequences. Zimbabwe's problems were exacerbated by the survival strategies implemented by the central bank. At the height of the crisis, the central bank was involved in all aspects of the economy, including the distribution of food and other basic commodities under a programme known as the Basic Commodities Supply Side Intervention (BACCOSSI). It had also virtually taken over the functions of the Ministry of Finance and other departments (Parsons, 2007; UNDP, 2008b). The central bank's widespread intervention in the economy fuelled inflation even more, and contributed to severe distortions and heavy losses in many economic sectors. These losses were estimated at 75\% of GDP in 2006 (Muňoz, 2007; UNDP, 2008b).

A dramatic downturn in production also occurred during the crisis period. For example, production slumped to $30 \%$ of capacity on average, and to between 12 and $15 \%$ in some industries. Some firms even closed down as they battled to get scarce foreign currency and raw materials (European Commission, 2007). Many public utilities were not operational and, where services were available, the quality was poor. Not surprisingly, frustration among consumers was the order of the day (Moss and Patrick, 2006; Parsons, 2007; Government of Zimbabwe, 2009). There was a mass exodus of manpower from the country - estimated at 3.4 million people - as well as capital flight, which exacerbated the capacity problems that firms experienced (Moss and Patrick, 2006; Parsons, 2007). Agriculture was particularly hard hit as production on the farms declined sharply, causing the country that had once been a net exporter of food to become a net importer of food (Parsons, 2007).

The first step in the recovery process was taken when the Government of National Unity unveiled the Short Term Emergency Recovery Programme (STERP) II on 23 December 2009. With an extended time horizon from 2010 to 2012, the programme had as its main objective to progress from a period of stabilisation to one of sustainable economic growth. This would involve bringing about a recovery in the country's GDP, creating jobs, 
rehabilitating the infrastructure, encouraging the sustainable use of natural endowments, and achieving a robust balance of payments. STERP II also recognised that the growth in output in the country's productive sectors needed to be underpinned by market-friendly trade and export promotion policies, research and development in the science and technology sectors, and the active promotion of small and medium enterprises. Furthermore, the government intended to develop a legal institutional and policy framework that would clear the way for the implementation of public-private partnership projects.

A Medium Term Plan (MTP), spanning the period 2011 to 2015, was launched on 7 July 2011, one year later than originally scheduled (Biti, 2011). According to the government of Zimbabwe (2010), the theme of the MTP is transformation and the development of a globally competitive economy, which is characterised by an expanding job market, and the pervasive influence of equity, freedom and democracy. The objectives of the MTP are, inter alia: macroeconomic and political stability, good governance, a diversified economy with very high growth rates, fully accessible social services, a heightened state of rural development, modern science and technology being at the centre of the country's industrial and commercial output, a vibrant and dynamic cultural environment, progressive and responsible management, and equal opportunities for all. To give weight to the MTP, the government intends to establish a Zimbabwe International Marketing Council (ZIMC) whose work will be focused on changing local and international perceptions about Zimbabwe, and bringing respectability to 'Brand Zimbabwe' (Government of Zimbabwe, 2010).

It is clear that the reconstruction of post-conflict economies such as Zimbabwe is a complicated, drawn-out process. In addition, the objectives, phases and strategies associated with reconstruction are too often focused on providing economy-wide solutions, with scant attention being paid to the micro-issues of firms that need to retrieve their competitiveness and deliver stronger output and employment opportunities. The sections that follow will show how this gap can be bridged by outlining the elements of microeconomic competitiveness put forward by Porter (2003) and analysing relevant firm-level data for Zimbabwe.

\section{MICROECONOMIC COMPETITIVENESS IN ZIMBABWE: EMPIRICAL EVIDENCE}

Porter (2003) argued that stable institutions and sound macro-policies create an environment conducive to growth and development, but it is competitive firms that grasp the opportunities presented and create valuable goods and services. Competitiveness can be described as productivity or efficiency. The microeconomic foundations of productivity, according to Porter, are company sophistication, the quality of the business environment and the state of cluster development. Owing to data constraints, this paper focuses only on the first two foundations.

Company sophistication has to do with the operational effectiveness of firms, as well as their innovation strategies with respect to production and service delivery. The business environment is best described in terms of Porter's Diamond Model and consists of four interrelated areas:

- The quality of factor conditions (which refer to human, physical and knowledge resources, as well as capital and infrastructure)

- $\quad$ The context for firm strategy and rivalry (which refers to how firms plan for success, and the extent to which competition is forcing firms to adapt their offerings and become more competitive)

- The quality of local demand conditions (which, if sophisticated, could put pressure on firms to innovate faster and bring more competitive product and service offerings to the market)

- $\quad$ The presence of related and supporting industries (whose role it is to provide inputs and complementary services to facilitate the production process)

The Diamond Model demonstrates that true competitiveness has less to do with a country having natural factor endowments, such as land and natural resources, and more to do with firms having the right business climate, incentives and encouragement.

In light of the above framework, economic development can be seen as "a sequential process of building interdependent microeconomic capabilities, shifting company strategies, improving incentives and increasing 
rivalry" (Porter, 2003:35). The objectives of Zimbabwe's Medium Term Plan can be mapped to this view of microeconomic competitiveness, as shown in Table 1.

Table 1. Linking Zimbabwe's MTP To The Micro-Environment

\begin{tabular}{ll}
\hline \multicolumn{1}{c}{ Microeconomic Business Environment } & \multicolumn{1}{c}{ Medium-Term Plan } \\
\hline The quality of factor conditions & Political stability, macroeconomic stability, good governance \\
The context for firm strategy and rivalry & $\begin{array}{l}\text { Political stability } \\
\text { Good governance, access to social services, acceleration of }\end{array}$ \\
The quality of local demand conditions & $\begin{array}{l}\text { rural development } \\
\text { Diversified economy, development and utilisation of modern } \\
\text { science and technology }\end{array}$ \\
\hline
\end{tabular}

Table 1 shows that the quality of factor conditions, or inputs, will be influenced by political and macroeconomic stability. In addition, stability and predictability of the political and policy landscape are prerequisites for investment in physical resources and human capital. Furthermore, the rules of the game need to be clear if firms are to compete successfully, and this requires political stability. The nature and sophistication of local demand is a key factor in firms' quest to be competitive and this, in turn, is very much a function of development in the economic and social spheres. Finally, for related and supporting industries to grow, a country needs a modern, diversified economy.

These broad-brush links between macro-objectives and the micro-environment serve to illustrate that reconstruction on the scale envisaged for a post-conflict economy will be a slow process. While a policy initiative such as the Medium Term Plan can help to create the right environment for growth, it is firms that have the power and responsibility to bring about the necessary changes by following new strategies, adopting different investment models, and creating new institutions with a view to expanding capacity.

Porter (2003) measured microeconomic competitiveness at the firm level using a range of indicators. In his approach, company strategy and operations are assessed in the light of factors such as the sophistication of the production process, the nature of evident competitive advantages, the extent of staff training being conducted, whether the marketing effort is appropriate and effective, and the willingness of the management/leadership to delegate authority. The microeconomic business environment is judged in the light of factor conditions, demand conditions, related and supporting industries, and the context for firm strategy and rivalry. Factor conditions are reflected in firms' views on the quality of the country's physical infrastructure, administrative infrastructure (judicial independence, legal recourse and bureaucratic red tape), human resources (quality of schools), technological infrastructure (availability of engineers, quality of research) and capital markets (sophistication of, and access to, finance facilities). Measures of demand conditions include consumer sophistication, government procurement policies and practices, and regulatory standards. The importance of related and supporting industries is reflected in firms' views on the quality of local suppliers and the availability of components, parts and machinery, as well as specialised services. Finally, the impact of firm strategy and rivalry is measured in terms of the extent of subsidies, favouritism shown by government officials, the level of co-operation in labour-employer relations, and the effectiveness of competition policy and tariff liberalisation.

So is there a way of gauging the microeconomic competitiveness of firms in a post-conflict economy such as Zimbabwe? The World Economic Forum's 2011/2012 Global Competitiveness Index (or GCI) incorporates a number of elements that can provide insight into microeconomic competitiveness at the country and firm level. Table 2 shows how company sophistication is evidenced in a number of GCI indicators. Table 3 shows the correlation between the four areas of Porter's Diamond and GCI indicators. In both tables, Zimbabwe's relative rankings (out of 142 countries surveyed in the World Economic Forum's 2011/2012 report) are shown in brackets. 
Table 2. Linking Company Sophistication With GCI Indicators For Zimbabwe

\begin{tabular}{ll}
\hline \multicolumn{1}{c}{ Company Sophistication } & \multicolumn{1}{c}{ Global Competitiveness Index } \\
\hline Company sophistication & Production process sophistication (128) \\
& Nature of competitive advantage (140) \\
Extent of staff training (78) & Extent of marketing (119) \\
Willingness to delegate authority (63) & Capacity for innovation (122) \\
& Company spending on R\&D (112) \\
Value chain breadth (140) \\
Control of international distribution (115) \\
Reliance on professional management (23) \\
Extent of performance-based compensation (134) \\
Prevalence of foreign licensing technology (132)
\end{tabular}

Source: Global Competitiveness Index (2011/2012:375)

Table 3. Linking The Micro Environment With GCI Indicators For Zimbabwe

Microeconomic Business Environment

The quality of factor (input) conditions
The context for firm strategy and rivalry

\section{Global Competitiveness Index}

Overall infrastructure quality (115)

Railroad infrastructure quality (62)

Port infrastructure quality (59)

Air transport infrastructure quality (110)

Electricity supply quality (134)

Cell phones per 100 people (118)

Internet users per 100 people (108)

Police protection of businesses (127)

Judicial independence (118)

Adequacy of public sector legal recourse (130)

Administrative burden for start-ups (94)

Extent of bureaucratic red tape (81)

Quality of management schools (70)

Quality of the education system (33)

Quality of maths and science education (57)

Patents per capita (90)

Availability of scientists and engineers (124)

Quality of scientific research institutions (105)

University/industry research collaboration (101)

Intellectual property protection (90)

Availability of financial services (116)

Venture capital availability (132)

Ease of access to loans (110)

Financing through the equity market (65)

Favouritism in decisions of government officials (113)

Cooperation in labour-employer relations (86)

Efficacy of corporate boards (36)

Prevalence of trade barriers (65)

Intensity of local competition (94)

Extent of market dominance (70)

Effectiveness of antitrust policy (84)

Trade tariffs (\% duty) (139)

The quality of local demand conditions

Buyer sophistication (86)

Government procurement of advanced technology products (130)

Domestic market size index (136)

The presence of related and supporting industries

State of cluster development (122)

Local availability of specialised research and training

services (105)

Local supplier quantity (117)

Source: World Economic Forum (2011/2012) 
The Global Competitiveness Index has many other indicators that are not featured in Tables 2 and 3. However, the information in the tables presents a compelling picture of the upheavals that the Zimbabwean economy has undergone. To understand what it all means for the competitiveness of firms, one has to drill down deeper. The subsections that follow present the results of an empirical analysis of firm-level data from the World Bank Enterprise Survey. The results provide a general profile of Zimbabwean firms and the micro-environment in which they must aim to be competitive. From this, it is possible to draw some key conclusions that will help to put the post-conflict reconstruction process into sharper perspective.

\section{Questionnaire Design}

The World Bank Enterprise Survey's 2011 dataset contained information on 598 firms (World Bank, 2011b). These were broken down into 148 large firms, 221 medium firms and 229 small firms. The questionnaire was comprehensive and was divided into a number of sections covering different business-related aspects, including: general firm information, infrastructure and services, sales and supplies, degree of competition, capacity, land and permits, innovation, crime, finance, business-government relations, labour, AIDS and sickness, the business environment and firm performance.

\section{Analysis Of Results}

\section{A Quick Overview}

On being asked to name the obstacles that they face, the respondent firms gave the main obstacles as being: difficulty in accessing finance, political instability, competition from the informal sector, unreliable electricity supply, and the tax rate. When the responses were compared in terms of firm size, both small firms (1-19 employees) and medium firms (20-99 employees) put difficulty in accessing finance at the top of the list, whereas large firms (100+ employees) said that political instability was their biggest obstacle. This prompts questions about the interrelationship between politics and economics in post-conflict reconstruction efforts.

Because of the central role played by politics in any reconstruction process, a political instability identifier was built into one of the questions in the questionnaire. In this regard, firms were asked to indicate what their biggest obstacle was. Those firms that chose political instability were given a value of 1 (politically constrained [PC] firms) and those that named another obstacle were given a value of 0 (non-politically constrained [non-PC] firms). Table 4 distinguishes between some of the basic characteristics of each group. While there are more firms in Zimbabwe that do not see political instability as their biggest obstacle than those that do, it is interesting that the politically constrained firms are more established, employ more staff, and generate higher domestic and export sales.

Table 4. General Differences Between PC And Non-PC Firms

\begin{tabular}{lcc}
\hline \multicolumn{1}{c}{ General } & Politically Constrained Firms & Non-Politically Constrained Firms \\
\hline Number of firms & $179(30 \%)$ & $419(70 \%)$ \\
\hline $\begin{array}{l}\text { Average total annual sales over the last } \\
\text { fiscal year (US\$) }\end{array}$ & $\$ 8,739,552$ & $\$ 4,081,069$ \\
\hline Average value of exports in 2010 & $\$ 3,636,569$ & $\$ 2,720,041$ \\
\hline $\begin{array}{l}\text { Average \% capacity utilisation in the } \\
\text { last fiscal year }\end{array}$ & $48 \%$ & $44 \%$ \\
\hline $\begin{array}{l}\text { Average number of full-time employees } \\
\text { at the end of the last fiscal year }\end{array}$ & 126 & 81 \\
\hline Average age of the firm & 39 & 33 \\
\hline
\end{tabular}

\section{Comparing PC And Non-PC Companies In Zimbabwe}

To compare politically constrained firms and non-politically constrained firms, and to determine whether or not the differences between them are significant, cross-tabulations and one-way ANOVA analyses were performed. The results are presented in Tables 5 and 6. 
Firstly, in terms of company sophistication, the significant differences appear to be in the area of technology (see Table 5). In general, more politically constrained than non-politically constrained firms use technology under licence from a foreign-owned company, have an internationally recognised quality certification, and have their own website.

Table 5. Company Sophistication

\begin{tabular}{lcc}
\hline \multicolumn{1}{c}{ Company Sophistication } & PC & Non-PC \\
\hline New improvements & 62 & 58 \\
\hline$\%$ of firms that have introduced new products or services & 69 & 64 \\
$\%$ of firms that have introduced new or significantly improved marketing methods (last & 61 & 59 \\
$\begin{array}{l}\text { \% years) } \\
\text { structures or management processes }\end{array}$ & 62 & 58 \\
$\%$ of firms that have introduced any new or significantly improved logistical or & & \\
business support processes & & \\
\hline Technology & $23^{*}$ & $11^{*}$ \\
\hline$\%$ of firms that use licensed technology from a foreign-owned company & $22^{*}$ \\
$\%$ of firms that have an internationally recognised quality certification & $47^{*}$ & $30^{*}$ \\
\hline
\end{tabular}

* Significant at the $5 \%$ level

** Significant at the $10 \%$ level

Table 6 sets out the factors that shape the microeconomic business environment. Only two of the interrelated areas of Porter's Diamond reveal significant differences between the PC and non-PC groups, namely factor (input) conditions and firm strategy and rivalry.

The first collection of factors under factor (or input) conditions relates to electricity. Electricity is reportedly a greater business impediment for the non-politically constrained firms than it is for the politically constrained firms. More specifically, non-politically constrained firms have to wait longer for connections and are more severely affected by power outages and the subsequent loss of sales. One reason for the difference between the two groups of firms might be that politically constrained firms generally have higher shares or ownership in power generators. The second set of factors in this category relates to connectivity and Internet facilities. It appears that, on average, politically constrained firms have better Internet connections and are more inclined to communicate with buyers and suppliers via email. The third set of factors is concerned with a number of business issues. Politically constrained firms experience more obstacles in obtaining business licences and permits, whereas non-politically constrained firms experience more difficulty with an inadequately educated workforce. On the plus side, however, politically constrained firms invest more in their human capital by training their employees. The final set of factors in this category relates to finance, and the results show that non-politically constrained firms, on average, find it more difficult to access finance than the politically constrained firms, and that this is an impediment to their achieving higher capacity utilisation.

When it comes to firm strategy and rivalry, it appears that, on average, non-politically constrained firms feel the competitive threat posed by the informal sector more acutely than politically constrained firms do. 
Table 6. Microeconomic Business Environment

\begin{tabular}{|c|c|c|}
\hline Factor (Input) Conditions & $\mathbf{P C}$ & Non-PC \\
\hline \multicolumn{3}{|l|}{ Electricity-related } \\
\hline Avg. no. of power outages per month over the last fiscal year & $7 *$ & $8 *$ \\
\hline$\%$ of firms that shares or owns a generator & $60 * *$ & $52 * *$ \\
\hline Avg. $\%$ of sales lost due to power outages & $8 * *$ & $11 * *$ \\
\hline Avg. no. of days to receive an electrical connection service & $24 * *$ & $41 * *$ \\
\hline$\%$ of firms that experience difficulty with electricity & 68 & 75 \\
\hline \multicolumn{3}{|l|}{ Connectivity and web-related } \\
\hline Avg. no of days to receive a telephone connection & 24 & 44 \\
\hline$\%$ of firms with high-speed connections on their premises & $67 *$ & $56 *$ \\
\hline$\%$ of firms that communicate with buyers and suppliers by email & $89 *$ & $79 *$ \\
\hline$\%$ of firms that experience difficulty with telecoms & 14 & 20 \\
\hline$\%$ of firms that experience difficulty with transport & 22 & 23 \\
\hline \multicolumn{3}{|l|}{ Business-related } \\
\hline$\%$ of firms that experience difficulty with business licensing and permits & $35^{*}$ & $33 *$ \\
\hline$\%$ of firms that experience difficulty with an inadequately educated workforce & $10 *$ & $13 *$ \\
\hline$\%$ full time production employees that received training in last fiscal year & $39 *$ & $29 *$ \\
\hline \multicolumn{3}{|l|}{ Finance-related } \\
\hline$\%$ of firms that experience difficulty with access to finance & $76^{*}$ & $85^{*}$ \\
\hline $\begin{array}{l}\% \text { of firms that experience lack of financing mechanisms as reason for poor capacity } \\
\text { utilisation }\end{array}$ & $64 *$ & $87 *$ \\
\hline Avg. $\%$ of working capital obtained from internal funds/retained earnings & 86 & 82 \\
\hline \multicolumn{3}{|l|}{ Demand conditions } \\
\hline $\begin{array}{l}\% \text { of firms that experience uncertainty about future market prospects as reason for poor } \\
\text { capacity utilisation }\end{array}$ & 35 & 32 \\
\hline$\%$ of firms that secured a government contract over the last 12 months & 21 & 22 \\
\hline \multicolumn{3}{|l|}{ Related and supplying industries } \\
\hline $\begin{array}{l}\% \text { of firms that experience obsolete machinery and equipment as reason for poor } \\
\text { capacity utilisation }\end{array}$ & 71 & 74 \\
\hline $\begin{array}{l}\% \text { of firms that experience the unavailability of inputs of production as reason for poor } \\
\text { capacity utilisation }\end{array}$ & 62 & 57 \\
\hline \multicolumn{3}{|l|}{ Firm strategy and rivalry } \\
\hline$\%$ of firms that experience difficulty with labour regulations & 29 & 24 \\
\hline$\%$ of firms that compete against informal sector & $57 *$ & $76^{*}$ \\
\hline $\begin{array}{l}\% \text { of firms that experience difficulty with the practices of competitors in the informal } \\
\text { sector }\end{array}$ & $49 *$ & $70 *$ \\
\hline$\%$ of firms that experience difficulty with customs and trade regulations & 36 & 80 \\
\hline$\%$ of firms that experience difficulty with import tariffs & 24 & 18 \\
\hline $\begin{array}{l}\% \text { of firms that experience the excessive abundance of cheap imports as reason for poor } \\
\text { capacity utilisation }\end{array}$ & 56 & 68 \\
\hline
\end{tabular}

* Significant at the 5\% level

** Significant at the $10 \%$ level

\section{CONCLUSION}

Competitive firms are the main drivers of economic growth. While governments need to provide an enabling macro-environment so that business can be conducted in an efficient manner, it is firms themselves that need to grasp the opportunities at their disposal and put valuable goods and services into the market place. Achieving competitiveness at the micro- or firm level in post-conflict economies can be particularly challenging because the reconstruction effort is often focused on achieving political and macroeconomic stability, while the everyday concerns linked to running a business in a complex, transformational society are not given the same degree of attention.

This paper has lifted the lid on the microeconomic aspects of post-conflict reconstruction, an area that has received little attention to date in the literature. Specifically, an analysis was conducted into how firms in Zimbabwe, a post-conflict country with a seriously troubled recent past, are addressing their day-to-day challenges and what they view as their most debilitating obstacles. A distinction was made in the analysis between those firms 
that consider political instability in the country to be their biggest obstacle (and are therefore dubbed politically constrained [PC] firms) and those firms that consider some other factor to be their biggest obstacle (and are referred to as non-politically constrained [non-PC] firms). The responses from the two groups of firms revealed some interesting trends. Compared with the non-PC firms, PC firms have been in business longer, have a larger workforce, and generate higher domestic and export sales revenue. They are also more technologically responsive, more quality driven, and have invested in, for example, power generators to cope in times of electricity outages. Together, these broad attributes tend to paint a picture of firms that are more established and in some respects more professional, have conquered many of the typical challenges that confront businesses - from finding markets to expanding production capacity and managing cashflow - and are intent on improving their competitiveness by embracing new technologies, etc. Given their possibly tried and tested approach to running their operations, these firms might find the political dynamics in the country troubling, because there is ever-present uncertainty. The nonPC firms, on the other hand, being smaller and less well established, are likely to be more concerned about issues that confront younger firms, e.g. acquiring finance, dealing with competition from the informal sector, the impact of power outages on production (in the absence of a backup generator), and so on. Consequently, they have not been as intent as the PC firms on devising forward-thinking strategies to enhance their technological capabilities, quality standards and presence in the local and international markets.

Clearly, firms in Zimbabwe are coping with the reconstruction challenges at different tempos; however, what seems evident is that less well-resourced (non-PC) firms are less preoccupied with the political atmosphere in the country than the more established (PC) firms. PC firms, having progressed to a reasonable level of development, are more inclined to view political instability as a major deterrent, because it affects their long-term expansion plans and their ability to attain competitiveness in the true sense of the word - lofty ideals that many of their non-PC counterparts are not yet aspiring to.

\section{AUTHOR INFORMATION}

Prof Marianne Matthee is an associate professor at the School of Economics at the North-West University in Potchefstroom, South Africa.

Prof Waldo Krugell is the director of the School of Economics at the North-West University in Potchefstroom, South Africa.

Dr Macleans Mzumara is a lecturer at the School of Economics at the Bindura University of Science Education in Harare, Zimbabwe. (This paper forms part of his PhD thesis completed at the North-West University [Potchefstroom Campus], South Africa.)

\section{REFERENCES}

African Development Bank. (2010). Zimbabwe country brief. Retrieved from http://www.afdb.org/fileadmin/ uploads/afdb/Documents/Project-and-Operations/Zimbabwe\%20Country\%20Brief 02.pdf

Ali, A.G.A. (2009). A policy framework for transiting from post-conflict recovery to sustainable development in Sub Saharan Africa. Journal of African Economies, 18(1):12-52.

Anderlini, S.N. \& El-Bushra, J. (2004). Post conflict reconstruction. Retrieved from http://www.inclusivesecurity.org/wpcontent/uploads/2012/04/39_post_conflict.pdf.

Anderson, I. (2005). Fragile states: What is international experience telling us? Retrieved from http://aid.dfat.gov.au/Publications/Documents/fragile_states.pdf.

Anderson, E., Christiansen, K. \& Putnam, R. (2007). Application of the Performance Based Allocation System to Fragile States. Retrieved from http://www.odi.org.uk/publications/194-performance-based-allocation-system-fragilestates.

Biti, T. (2011). National budget 2012 statement by the Minister of Finance, Government of Zimbabwe. Retrieved from www.zimtreasury.org.

Brück, T., Naudé, W.A. \& Verwimp, P. (2011). Small Business, Entrepreneurship and Violent Conflict in Developing Countries. Journal of Small Business and Entrepreneurship, 24(2):161-178.

Collier, P. \& Duponchel, M. (2013). The Economic Legacy of Civil War: Firm-level Evidence from Sierra Leone, Journal of Conflict Resolution, 57(1):65-88.

Copyright by author(s); CC-BY 
Collier, P., Hoeffler, A. \& Söderbom, M. (2008). Post-conflict risks. Journal of Peace Research, 45:463.

European Commission. (2007). Needs assessment of trade and trade related assistance for Zimbabwe. Harare: European Commission.

Government of Zimbabwe. (2009). Short term emergency recovery programme (STERP) I. Harare: Printflow.

Government of Zimbabwe. (2010). Medium term plan (MTP) 2011-2015. Harare: Ministry of Economic Planning and Development.

Guillaumount, P. \& Jeanneney, S.G. (2009). State fragility and economic vulnerability: What is measured and why. Retrieved from http://www.cerdi.org/uploads/ed/2009/2009.18.pdf.

IMF. (2010). Zimbabwe: challenge and policy options after hyperinflation. Retrieved from http://www.imf.org/external/pubs/ft/dp/2010/afr1003.pdf.

Makochekanwa, A. \& Kwaramba, M. (2009). State fragility: Zimbabwe's horrific journey in the new millennium. European Development (ERD) Conference. May 21-23, Accra: Ghana.

Media Monitoring Project Zimbabwe (MMPZ). (2009). The propaganda war on electoral democracy. Harare: MMPZ.

Michailof, S. Kostner, M. \& Devictor, X. (2002). Post-conflict recovery in Africa: an agenda for African region Retrieved from http://www.worldbank.org/afr/wps/wp30.pdf.

Mlambo, M.K., Kamara, A.B. \& Nyenda, M. (2009). Financing post-conflict recovery in Africa: the role of international development assistance. Journal of African Economies, 18(1):153-176.

Moss, T. \& Patrick, S. (2006). The Day After Comrade Bob: Applying Post-Conflict Recovery Lessons to Zimbabwe Retrieved from http://www.cgdev.org/files/5300_file_WP 72.pdf.

Muňoz, S. (2007). Central bank quasi-fiscal losses and high inflation in Zimbabwe: a note. IMF Working Paper wp/07/98, Retrieved from http://www.imf.org/external/pubs/ft/wp/2007/wp0798.pdf.

Nhema, A. \& Zeleza, P.T. (2008). The resolution of African conflict, the management of conflict resolution and post conflict reconstruction: South Africa, Namibia, Mozambique, Somalia, Sudan, Kenya, Uganda, Mauritius. Athens, OH: Ohio University Press. p7.

Parsons, R. (2007). After Mugabe goes- the economic and political reconstruction of Zimbabwe. South African Journal of Economics, 75(4):599-615.

Porter, M.E. (2003). Building the Microeconomic Foundations of Prosperity: Findings from the Microeconomic Competitiveness Index Retrieved from http://www.weforum.org/pdf/Gcr/GCR_2003_2004/BCI_Chapter.pdf.

Reinikka, R. \& Collier, P. (2001). Uganda's recovery: The role of farms, firms, and government. World Bank Publications.

The Catholic Commission for Justice and Peace in Zimbabwe (2001). Crisis of governance: Report on political violence in Zimbabwe, Harare: The Catholic Commission for Justice and Peace in Zimbabwe.

UNDP. (2005). Sustaining post-conflict economic recovery: lessons and challenges. Bureau for Crisis Prevention and Recovery. New York, NY: UNDP.

UNDP. (2008a). Post-conflict economic recovery: enabling local ingenuity. Bureau for Crisis Prevention and Recovery. New York, NY: UNDP.

UNDP. (2008b.). Comprehensive economic recovery in Zimbabwe: A discussion document. Harare: UNDP.

The United Nations. (2002). Women, peace and security, Retrieved from http://www.un.org/womenwatch/ daw/public/eWPS.pdf .

World Bank. (1998). Post-conflict reconstruction: The role of the World Bank. Retrieved from http://wwwwds.worldbank.org/servlet/WDSContentServer/WDSP/IB/1998/04/01/000009265_3980624143531/Rendered/P DF/multi_page.pdf

World Bank. (2011a). Zimbabwe country overview (as updated on September 2010) Retrieved from http://web.worldbank.org/WBSITE/TLEXTERNAL/COUNTRIES/AFRICAEXTN,menu pk-375746pagepk:141132Tthesitepk.375736,00html.

World Bank. (2011b.). Enterprise survey for Zimbabwe. Retrieved from http://www.enterprisesurveys.org/ Data/ExploreEconomies/2011/zimbabwe .

World Bank. (2013). Harmonised list of fragile situations. Retrieved from http://siteresources.worldbank.org/ EXTLICUS/Resources/511777-1269623894864/FCSHarmonizedListFY13.pdf.

World Economic Forum. (2011/2012). Global Competitiveness Report, Country profile for Zimbabwe Retrieved from http://www.weforum.org/reports/global-competitiveness-report-2011-2012.

ZIMSTAT. (2010). Statistics. Retrieved from www.zimstats.co.zw. 